\title{
Molecular detection of extended-spectrum $\beta$-lactamase-producing Klebsiella pneumoniae isolates of chicken origin from East Java, Indonesia
}

\author{
Meutia Hayati ${ }^{1,2}$, Agustin Indrawati ${ }^{1}$, Ni Luh Putu Ika Mayasari ${ }^{1}$, Istiyaningsih Istiyaningsih ${ }^{2}$ and Neneng Atikah ${ }^{2}$
}

1. Division of Medical Microbiology, Faculty of Veterinary Medicine, Bogor Agricultural University-West Java, Indonesia; 2. Division of Bacteriology, National Veterinary Drug Assay Laboratory, Gunungsindur Bogor-West Java, Indonesia. Corresponding author: Meutia Hayati, e-mail: meutiakhoir@yahoo.com

Co-authors: AI: titin.seta@gmail.com, NLPIM: mayasari.ika@gmail.com, II: ningsagita29@yahoo.com, NA: neneng atikah.bbpmsoh@gmail.com

Received: 22-10-2018, Accepted: 01-03-2019, Published online: 19-04-2019

doi: 10.14202/vetworld.2019.578-583 How to cite this article: Hayati M, Indrawati A, Mayasari NLPI, Istiyaningsih I, Atikah N (2019) Molecular detection of extended-spectrum $\beta$-lactamase-producing Klebsiella pneumoniae isolates of chicken origin from East Java, Indonesia, Veterinary World, 12(4): 578-583.

\begin{abstract}
Background and Aim: Klebsiella pneumoniae is one of the respiratory disease agents in human and chicken. This bacterium is treated by antibiotic, but this treatment may trigger antibiotic resistance. Resistance gene in K. pneumoniae may be transferred to other bacteria. One of the known resistance genes is extended-spectrum $\beta$-lactamase (ESBL). This research aimed to study $K$. pneumoniae isolated from chicken farms in East Java, Indonesia, by observing the antibiotic resistance pattern and detect the presence of ESBL coding gene within the isolates.
\end{abstract}

Materials and Methods: A total of $11 \mathrm{~K}$. pneumoniae isolates were collected from 141 chicken cloacal swabs from two regencies in East Java. All isolates were identified using the polymerase chain reaction method. Antimicrobial susceptibility was determined by agar dilution method on identified isolates, which then processed for molecular characterization to detect ESBL coding gene within the $K$. pneumoniae isolates found.

Results: The result of antibiotic sensitivity test in 11 isolates showed highest antibiotic resistance level toward ampicillin, amoxicillin, and oxytetracycline $(100 \%, 100 \%$, and $90.9 \%)$ and still sensitive to gentamicin. Resistance against colistin, doxycycline, ciprofloxacin, and enrofloxacin is varied by $90.9 \%, 54.5 \%, 27.3 \%$, and 18.2\%, respectively. All isolates of $K$. pneumoniae were classified as multidrug resistance (MDR) bacteria. Resistance gene analysis revealed the isolates harbored as $b l a_{\mathrm{SHV}}(9.1 \%)$, bla $_{\mathrm{TEM}}(100 \%)$, and bla $_{\mathrm{CTX}-\mathrm{M}}(90.9 \%)$.

Conclusion: All the bacterial isolates were classified as MDR bacteria and harbored two of the transmissible ESBL genes. The presence of antibiotic resistance genes in bacteria has the potential to spread its resistance properties.

Keywords: antibiotic resistance, chicken, extended-spectrum $\beta$-lactamase, Klebsiella pneumoniae.

\section{Introduction}

Klebsiella pneumoniae is a Gram-negative, rodshaped, non-motile, encapsulated opportunistic pathogen. This bacterium is part of the Enterobacteriaceae family, anaerobic facultative, measuring $1.0 \mathrm{~mm}$ with 0.6-6.0 mm length with mucoid colony [1]. K. pneumoniae causes an abscess in the liver and included as one of the emerging diseases in the world. Between the mid-80s and 90s, there was an increasing report of liver abscess or metastatic infection in eyes caused by hypervirulent $K$. pneumoniae in Taiwan, Hong Kong, and Singapore. This increase is also found in North America, South America, the Caribbean, Europe, Middle East, Australia, Africa, and South Africa [2]. $K$. pneumoniae is also responsible for a significant proportion of hospital-acquired infections including

Copyright: Hayati, et al. Open Access. This article is distributed under the terms of the Creative Commons Attribution 4.0 International License (http://creativecommons.org/licenses/by/4.0/), which permits unrestricted use, distribution, and reproduction in any medium, provided you give appropriate credit to the original author(s) and the source, provide a link to the Creative Commons license, and indicate if changes were made. The Creative Commons Public Domain Dedication waiver (http://creativecommons.org/ publicdomain/zero/1.0/) applies to the data made available in this article, unless otherwise stated. septicemias, urinary tract infections, pneumonia, and soft tissue infections, especially in the immunocompromised hosts such as the neonate [3]. Other than nosocomial infection, $K$. pneumoniae also spread through foodstuff and thus often regarded as a foodborne disease agent. K. pneumoniae can be found in foodstuffs such as seafood, frozen food, and fresh chicken meat [4]. K. pneumoniae is not only a pathogen to human, but it is also a respiratory disease agent in chicken which can cause production loss or even death. In research conducted by Alexandria University, Egypt, $10 \%$ of 150 specimens taken from chicken with respiratory disease contained $K$. pneumoniae [5].

Antibiotics are commonly used as therapy and disease control in humans and animals. However, widespread use of antibiotic may also trigger the rise of antibiotic resistance. Cases of multidrug resistance (MDR) in K. pneumoniae have been repeatedly reported. MDR is a case of isolates resistant against more than three types of antibiotics. MDR cases, especially from extended-spectrum $\beta$-lactamase (ESBL) group, have been reported from Klebsiella spp. isolate test in Shandong Poultry Slaughterhouse, China, where $96.7 \%$ of bacteria isolates were resistant against 
more than three types of antibiotics. Antibiotics tested were ceftazidime, cefoperazone, cefotaxime, cefepime, ampicillin, kanamycin, chloramphenicol, tetracycline, and ciprofloxacin [6]. A similar trend of resistance was observed among $102 \mathrm{~K}$. pneumoniae from 17 free-range chicken samples in Cape Town, South Africa. The isolates exhibited a high level of resistance toward ampicillin $(66.7 \%)$, nalidixic acid $(61.8 \%)$, tetracycline $(59.8 \%)$, and trimethoprim $(50.0 \%)$ but highly susceptible toward gentamicin $(3.9 \%)$ and ciprofloxacin $(4.8 \%)$. Almost $40 \%$ of the isolates were found to be MDR K. pneumoniae strains [1]. Another study, MDR enteric bacteria were isolated from turkey, cattle, and chicken farms and retail meat products in Oklahoma. Among the isolated species, multidrug-resistant $K$. pneumoniae was isolated from most of the collected samples. Therefore, a total of 132 isolates of $K$. pneumoniae were characterized. All isolates were resistant to ampicillin, tetracycline, streptomycin, gentamycin, and kanamycin [7]. This often causes antibiotic treatment to be ineffective and requires repeated antibiotic treatment using several different antibiotic groups.

Resistance gene in K. pneumoniae may be transferred to other bacteria. Based on several researches, it is known that resistance gene from $K$. pneumoniae can be transferred in vitro and in vivo [8,9]. One of the resistance genes located in the plasmid is ESBL coding gene. ESBL is an enzyme produced by Gram-negative bacillus bacteria that can hydrolyze penicillin, cephalosporin (Groups 1, 2, and 3), and monobactam [10]. ESBL coding genes and other antibiotic resistance genes which are part of antibiotic resistance integrons (ARI) are transmissible horizontally through plasmid sequence insertion, transposon and conjugation. Several reports stated that the presence of integrons in ESBL coding gene plasmid has a high correlation with MDR. This may occur if the ARI and ESBL coding genes are within one integron complex or within one plasmid $[11,12]$.

Majority of a poultry farm in Indonesia uses antibiotics as treatment $(86.7 \%)$, prevention $(46.7 \%)$, and growth promotor to increase feed efficiency $(10 \%)$ [13]. This means the risk of antibiotic resistance in Indonesian poultry farm is very high and thus requires further study. This research aimed to study K. pneumoniae isolated from chicken farms in East Java, Indonesia, by observing the antibiotic resistance pattern and detect the presence of ESBL coding gene within the isolates.

\section{Materials and Methods}

\section{Ethical approval}

Ethical approval was not required in this study. However, samples were collected as per the standard sample collection procedure.

\section{Sample collections}

A total of 141 cloacal swabs were collected from healthy chickens with sterile swabs. The samples were taken from 47 intensive rearing system farms during
April-May 2017 spread in two regencies (Kediri and Blitar) in East Java, Indonesia.

\section{Isolation and Identification of $\boldsymbol{K}$. pneumoniae}

The cloacal swabs were inserted into test tubes containing sterile brain heart infusion broth (BHIB) (BD, Sparks, MD, USA) and incubated at $37^{\circ} \mathrm{C}$ for $24 \mathrm{~h}$. Loopfuls of the turbid suspension in the BHIB tubes were aseptically cultured on eosin methylene blue (EMB) agar (BD, Sparks, MD, USA) and incubated at $37^{\circ} \mathrm{C}$ for $18-24 \mathrm{~h}$. On EMB agar, Klebsiella spp. produced large, mucoid, pink-to-purple, and nonmetallic-green sheen colonies [14]. Klebsiella spp. was subcultivated on heart infusion agar (HIA) (BD, Sparks, $\mathrm{MD}, \mathrm{USA}$ ) at $37^{\circ} \mathrm{C}$ for $24 \mathrm{~h}$. Identification was carried out by biochemical tests using Microgen GN-ID A system (Microgen Bioproducts Ltd., United Kingdom).

Confirmatory test of $K$. pneumoniae was conducted according to the polymerase chain reaction (PCR) methods [15]. DNA was isolated using PrepMan reagent (Applied Biosystems, Foster City, CA) according to manufacturer's instructions. Species-specific primers were used for the amplification of $r p o B$ gene of $K$. pneumoniae (F-CAACGGTGTGGTTACTGACG and R-TCTACGAAGTGGCCGTTTTC). PCR was performed using HotStarTaq ${ }^{\mathrm{TM}}$ DNA Polymerase kit (Qiagen, Valencia, CA). The PCR master mix reagents for each genes target were as follows: $2.5 \mu \mathrm{L}$ PCR buffer (10×), $2.5 \mu \mathrm{L} \mathrm{MgCl} 2(25 \mathrm{mM}), 0.5 \mu \mathrm{L}$ dNTP mix (at $200 \mu \mathrm{M}), 2.5 \mu \mathrm{L}$ primary forward $(10 \mu \mathrm{M}), 2.5 \mu \mathrm{L}$ primary reverse $(10 \mu \mathrm{M}), 0.125 \mu$ L HotstarTaq DNA polymerase, $5 \mu \mathrm{L}$ DNA template, and $\mathrm{dH} 2 \mathrm{O}$ up to $25 \mu \mathrm{L}$.

The PCR process was used a thermocycler with a predenaturation cycle of $95^{\circ} \mathrm{C}$ for $15 \mathrm{~min}$, followed by a DNA amplification stage with 30 cycles $\left(94^{\circ} \mathrm{C}\right.$ for $1 \mathrm{~min}, 55^{\circ} \mathrm{C}$ for $1 \mathrm{~min}$, and $72^{\circ} \mathrm{C}$ for $1 \mathrm{~min}$ ) and final extension cycle of $72^{\circ} \mathrm{C}$ for $10 \mathrm{~min}$. Electrophoresis was conducted using $1.5 \%$ agarose gel, Tris-acetateEDTA (TAE) buffer $1 \times$ concentration, SYBR safe, loading dye, and DNA ladder/marker $100 \mathrm{bp}$.

\section{Antimicrobial susceptibility testing}

Each $K$. pneumoniae isolate was tested for antimicrobial susceptibility using eight antibiotics: Ampicillin, amoxicillin, doxycycline, gentamicin, oxytetracycline, enrofloxacin, colistin and ciprofloxacin (Sigma-Aldrich, St. Louis, MO, USA). Agar dilution was a quantitative susceptibility testing method because minimum inhibitory concentration values can be obtained using the method. In this method, twofold serial dilutions of an antibiotic made in MuellerHinton agar (MHA) (BD, Sparks, MD, USA). The concentration ranges evaluated were $0.25-512 \mu \mathrm{g} / \mathrm{ml}$. Bacterial suspensions were inoculated on the MHA and incubated at $37^{\circ} \mathrm{C}$ for $18-20 \mathrm{~h}$. The results were interpreted according to performance standards for antimicrobial susceptibility testing $27^{\text {th }}$ edition, Clinical and Laboratory Standards Institute guidelines. Antimicrobial susceptibility test against colistin was interpreted according to EUCAST guidelines. 
Escherichia coli reference strain ATCC 25922 was used as the susceptible reference strain in all tests $[16,17]$.

\section{Genomic DNA extraction}

Isolates were subcultured at $37^{\circ} \mathrm{C}$ overnight in HIA (BD, Sparks, MD, USA). The bacteria were extracted by boiling method using Ultra Sample Preparation Reagent (PrepMan ${ }^{\circledR}$, Applied Biosystems, Foster City, CA).

\section{Characterization of ESBL genes using PCR}

The presence of genes encoding ESBL was detected using PCR amplification. This study detected $b l a_{\mathrm{SHV}}[18], b l a_{\mathrm{TEM}}$ [6], and bla $a_{\text {СTX-M }}$ [19] gene using primers from the previous study. The PCR master mix reagents for each genes target were as follows: $2.5 \mu \mathrm{L}$ PCR buffer (10×), $2.5 \mu \mathrm{L} \mathrm{MgCl} 2(25 \mathrm{mM}), 0.5 \mu \mathrm{L}$ dNTP mix (at $200 \mu \mathrm{M}$ ), $2.5 \mu \mathrm{L}$ primary forward $(10 \mu \mathrm{M}), 2.5 \mu \mathrm{L}$ primary reverse $(10 \mu \mathrm{M}), 0.125 \mu \mathrm{L}$ HotstarTaq DNA polymerase, $5 \mu \mathrm{L}$ DNA template, and $\mathrm{dH}_{2} \mathrm{O}$ up to $25 \mu \mathrm{L}$.

The PCR process was used a thermocycler with a predenaturation cycle of $95^{\circ} \mathrm{C}$ for $15 \mathrm{~min}$, followed by a DNA amplification stage with 30 cycles $\left(94^{\circ} \mathrm{C}\right.$ for $1 \mathrm{~min}, 54.5-60^{\circ} \mathrm{C}$ for $1 \mathrm{~min}$, and $72^{\circ} \mathrm{C}$ for $1 \mathrm{~min}$ ) and final extension cycle of $72^{\circ} \mathrm{C}$ for $10 \mathrm{~min}$. Electrophoresis was conducted using $1.5 \%$ agarose gel, TAE-EDTA buffer $1 \times$ concentration, SYBR safe, loading dye, and DNA ladder/marker $100 \mathrm{bp}$. A positive sample would show DNA band on the appropriate amplicon length as shown in Table-1 $[6,18,19]$. K. pneumoniae ATCC 700603 was used as a positive control against gene $b l a_{\mathrm{SHV}}$.

\section{Results}

Twenty-three isolates suspected as Klebsiella spp. were collected from 141 chicken cloacal swabs. From biochemical analysis obtained, about 13 samples characterize as the K. pneumoniae. All of the isolates were tested using PCR method to identify K. pneumoniae using gene $r p o B$ as a target. The visualization result of isolate PCR product from Blitar and Kediri showed that two isolates were negative to the rpoB gene. Hence, it could be confirmed that genotypically there were only 11 positive samples of $K$. pneumoniae (seven isolates from Blitar and four isolates from Kediri Regency).

Antimicrobial susceptibility test in 11 isolates of $K$. pneumoniae showed that all isolates were resistant to three or more antibiotics. The pattern of antimicrobial resistance is shown in Table-2. The highest number of resistances was against ampicillin, amoxicillin, and oxytetracycline $(100 \%, 100 \%$, and $90.9 \%$, respectively) which were the first antibiotics used. Isolates were still sensitive to gentamicin. Susceptibility test of colistin, doxycycline, ciprofloxacin, and enrofloxacin was varied at $90.9 \%, 45.5 \%, 45.4 \%$, and $36.4 \%$, respectively. The results of antibiotic resistance are shown in Table-3.

Molecular detection of ESBL encoding genes was performed on all isolates of $K$. pneumoniae resistant against $\beta$-lactam antibiotics. From 11 isolates of $K$. pneumoniae, the bla $a_{\mathrm{SHV}}$ gene was only detected in one sample $(0.9 \%)$ isolates (Figure-1). The bla $_{\mathrm{TEM}}$ gene was detected in all $K$. pneumoniae isolates $(100 \%)$ (Figure-2). o Based on PCR detection of the $b l \mathrm{a}_{\text {CTX-M }}$ gene, we found one isolate was negative while ten other isolates were positive for $b l a_{\text {CTX-M }}(90.9 \%)$ (Figure-3). The presence of these three ESBL encoding genes indicated that $K$. pneumoniae produces ESBL.

\section{Discussion}

The PCR results of rpoB gene showed from 13 suspected isolates in the biochemical analysis; only

Table-1: Primers sets for detection of ESBL encoding genes from Klebsiella pneumoniae.

\begin{tabular}{|c|c|c|c|c|c|}
\hline No. & Resistance gene & Primer & Annealing Temperature & Amplicon (bp) & References \\
\hline 1 & $b^{\prime} a_{\mathrm{SHV}}$ & $\begin{array}{l}\text { (F) 5'- CCTGTTAGCCACCCTGCC-3' } \\
\text { (R) 5'- CCGCAGATAAATCACCAC-3' }\end{array}$ & $60^{\circ} \mathrm{C}$ & 768 & {$[18]$} \\
\hline 2 & $b / a_{\text {TEM }}$ & $\begin{array}{l}\text { (F) 5'-ATTTCCGTGTCGCCCTTAT-3' } \\
\text { (R) 5'-CTACGATACGGGAGGGCTTA-3' }\end{array}$ & $54.5^{\circ} \mathrm{C}$ & 759 & [6] \\
\hline 3 & $b l a_{\mathrm{CTX}-\mathrm{M}}$ & $\begin{array}{l}\text { (F) 5-'ATGATGAAAAAATCGTTATGC-3' } \\
\text { (R) 5'-CAGCATCTCCCAGCCTAAT-3' }\end{array}$ & $57^{\circ} \mathrm{C}$ & 489 & [19] \\
\hline
\end{tabular}

$\mathrm{ESBL}=$ Extended-spectrum $\beta$-lactamase

Table-2: Antimicrobial resistance pattern of Klebsiella pneumoniae.

\begin{tabular}{|c|c|c|c|c|c|c|c|c|c|c|c|c|}
\hline \multirow[t]{2}{*}{ No. } & \multirow[t]{2}{*}{ Antibiotics } & \multicolumn{11}{|c|}{ Sample code } \\
\hline & & B2C & B12c & B13c & B27a & B29a & B29b & B31b & Kзb & K6b & K1Ob & K15a \\
\hline 1 & Ampicillin & $\mathrm{R}$ & $\mathrm{R}$ & $\mathrm{R}$ & $\mathrm{R}$ & $\mathrm{R}$ & $\mathrm{R}$ & $\mathrm{R}$ & $\mathrm{R}$ & $\mathrm{R}$ & $\mathrm{R}$ & $\mathrm{R}$ \\
\hline 2 & Amoxicillin & $\mathrm{R}$ & $\mathrm{R}$ & $\mathrm{R}$ & $\mathrm{R}$ & $\mathrm{R}$ & $\mathrm{R}$ & $\mathrm{R}$ & $\mathrm{R}$ & $\mathrm{R}$ & $\mathrm{R}$ & $\mathrm{R}$ \\
\hline 3 & Oxytetracycline & $\mathrm{S}$ & $\mathrm{R}$ & $\mathrm{R}$ & $\mathrm{R}$ & $\mathrm{R}$ & $\mathrm{R}$ & $\mathrm{R}$ & $\mathrm{R}$ & $\mathrm{R}$ & $\mathrm{R}$ & $\mathrm{R}$ \\
\hline 4 & Doxycycline & $\mathrm{R}$ & $\mathrm{R}$ & $\mathrm{R}$ & $\mathrm{R}$ & $\mathrm{R}$ & $\mathrm{R}$ & $\mathrm{S}$ & $\mathrm{S}$ & $\mathrm{S}$ & $\mathrm{S}$ & $\mathrm{S}$ \\
\hline 5 & Ciprofloxacin & $\mathrm{S}$ & $\mathrm{R}$ & $\mathrm{R}$ & I & I & $\mathrm{I}$ & $\mathrm{R}$ & $\mathrm{S}$ & $\mathrm{S}$ & $\mathrm{S}$ & $\mathrm{S}$ \\
\hline 6 & Enrofloxacin & I & $\mathrm{R}$ & $\mathrm{R}$ & $\mathrm{I}$ & I & I & $\mathrm{I}$ & $\mathrm{S}$ & $\mathrm{S}$ & $\mathrm{S}$ & $\mathrm{S}$ \\
\hline 7 & Colistin & $\mathrm{S}$ & $\mathrm{S}$ & S & $\mathrm{R}$ & $\mathrm{S}$ & $\mathrm{S}$ & $\mathrm{S}$ & $\mathrm{S}$ & $\mathrm{S}$ & $\mathrm{S}$ & $\mathrm{S}$ \\
\hline 8 & Gentamicin & $\mathrm{S}$ & $\mathrm{S}$ & $\mathrm{S}$ & $\mathrm{S}$ & $S$ & $\mathrm{~S}$ & $\mathrm{~S}$ & $\mathrm{~S}$ & $\mathrm{~S}$ & $S$ & $\mathrm{~S}$ \\
\hline Total & & 3 & 6 & 6 & 4 & 4 & 4 & 4 & 3 & 3 & 3 & 3 \\
\hline
\end{tabular}

$\mathrm{R}=$ Resistance, $\mathrm{S}=$ Susceptible, $\mathrm{I}=$ Intermediate 
Table-3: Antimicrobial susceptibility rate of Klebsiella pneumoniae isolates.

\begin{tabular}{llccc}
\hline Group & Antibiotic & Resistance (\%) & Intermediate (\%) & Susceptible (\%) \\
\hline 3-lactam & Ampicillin & 100 & 0 & 0 \\
Tetracycline & Amoxicillin & 100 & 0 & 0 \\
& Oxytetracycline & 90.9 & 0 & 9.1 \\
Fluoroquinolone & Doxycycline & 54.5 & 0 & 45.5 \\
& Ciprofloxacin & 27.3 & 27.3 & 45.4 \\
Polypeptide & Enrofloxacin & 18.2 & 45.4 & 36.4 \\
Aminoglycoside & Colistin & 9.1 & - & 90.9 \\
\hline
\end{tabular}

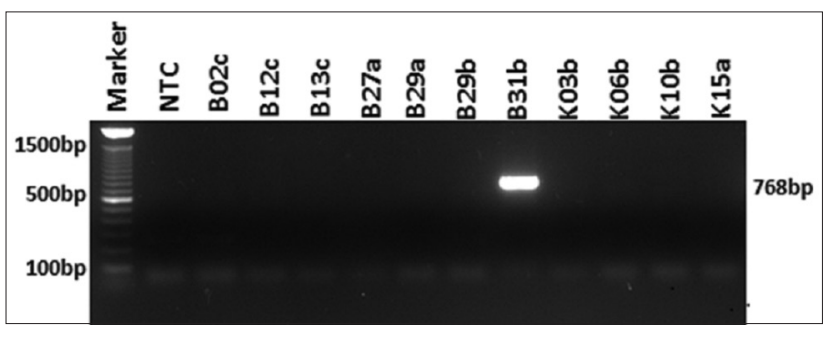

Figure-1: Amplification of bla ${ }_{\mathrm{SHV}}$ gene on Klebsiella pneumoniae. A total of one isolate (B31b) showed a positive result of $b / a_{\mathrm{SHV}}$. NTC: Non template control.

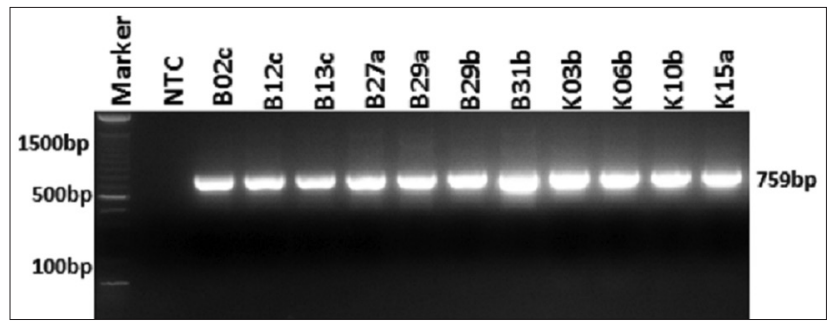

Figure-2: Amplification of bla $a_{\text {TEM }}$ gene on Klebsiella pneumoniae. All isolates showed positive results of bla ${ }_{\mathrm{TEM}}$. NTC: Non template control.

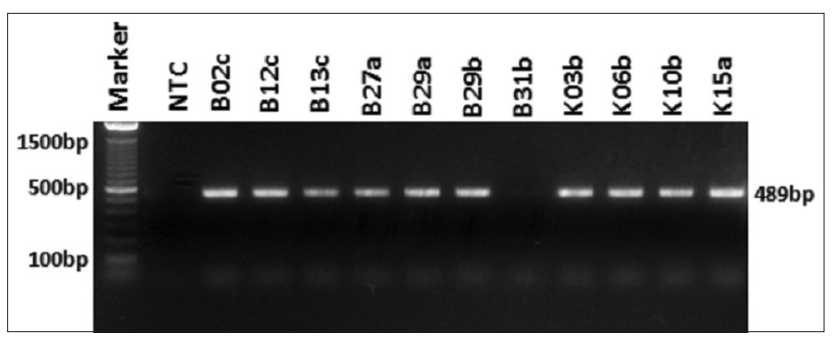

Figure-3: Amplification of bla ${ }$ gene on Klebsiella pneumoniae. A total of 10 isolates showed positive results of bla ${ }_{\text {СTX-M. }}$ NTC: Non template control.

11 samples showed a DNA band at a 108 bp amplicon length. These different results could be due to the false-positive results in biochemical analysis due to a delayed positivity test in ornithine decarboxylase and motility tests. This test will give a negative result to $K$. pneumoniae but for Enterobacter spp. and Shigella spp. will provide positive results. This biased test result could be avoided by increasing the incubation time from $24 \mathrm{~h}$ to $2-5$ days [20]. The use of genotyping techniques may address the problem of phenotypic identification. Identification of $K$. pneumoniae using rpoB gene target could be used more accurate and faster test times. Rapid and accurate identification would make it easier to take the most appropriate treatment [21].

The result of antimicrobial susceptibility tests shows that all $K$. pneumoniae isolates are the MDR bacteria. The case of MDR on K. pneumoniae causes longer treatment and difficult to cure. The antibiotic resistance pattern was expected to be a guide in choosing the right antibiotics for treatment. Widespread use of antibiotics without strict supervision may trigger antibiotics resistance. Until now, antibiotic is easy to obtain and may be applied without veterinarian supervision. As many as, $72.3 \%$ of chicken farmers in Indonesia are still using antibiotics without veterinarian supervision [13].

All the samples of cloacal swabs were taken from intensive farm. Intensive broiler rearing systems are associated with greater use of antibiotics for therapeutic purposes due to high stocking densities, stressful conditions, and fast growth rates. FAO (2008) reported that irrespective of dose, an estimated $75 \%$ of antimicrobial agents administered to intensively reared broilers may be excreted into the environment, leading to the development of antimicrobial-resistant bacterial strains in humans. Furthermore, evidence indicates that antimicrobial residues in manure might also be responsible for the contamination of soil, surface water, and groundwater resources close to farms involved in intensive broilers rearing activities [22].

Tested $\beta$-lactam groups were ampicillin and amoxicillin. Antimicrobial susceptibility test showed that all isolates were resistant to ampicillin and amoxicillin. This antibiotic has a broad-spectrum activity and thus often used for many applications. Since its introduction, the usage of ampicillin and amoxicillin in farms is very high. They are used as individual and flock treatment and as antibiotic growth promotor given from feed or drinking water.

From the test results, resistance against oxytetracycline is $90.9 \%$. This high resistance induces the use of second generation of tetracycline, namely doxycycline. However, resistance to doxycycline also rises, which can be seen from the percentage of resistant isolates, $54.5 \%$. Tetracycline is an antibiotic commonly used in farms in Indonesia and worldwide due to its efficacy as a broad-spectrum antibiotic, easily absorbed, cheap, and has minimum side effects $[13,23]$.

The most widely used antibiotics in chicken farms other than oxytetracycline are enrofloxacin 
and ciprofloxacin. Based on susceptibility test of ciprofloxacin and enrofloxacin from 11 isolates of $K$. pneumoniae, we found $45.4 \%$ were susceptible to ciprofloxacin and $36.4 \%$ isolates were susceptible to enrofloxacin. Fluoroquinolone has been classified by the World Health Organization as critically important in human medicine for its ability to treat infections from Campylobacter spp., Salmonella spp., and E. coli infections. To prevent further resistance, treatment using fluoroquinolone has been limited only for individual treatment, not a group. Overuse in farm-animal species can contribute to higher levels of resistance in human Salmonella, E. coli, and Campylobacter infections. Those countries which have banned or have never used fluoroquinolones in poultry have much lower levels of resistance in human bacterial infections than those countries which continue to use the drugs in poultry [24].

Gentamicin is still sensitive to all K. pneumoniae isolates. Gentamicin is aminoglycoside group highly important in treating bacterial infection in livestock and pet. According to OIE, these antibiotics were included in veterinary critically important, and if it ever loses its effectivity, there is a need for other antibiotics to replace. Its alternative is fluoroquinolone and colistin; however, these two antibiotics have been limited for usage in animal, being included as critically important in human medicine [25]. One of the $K$. pneumoniae isolates is already resistant to colistin.

ESBL bacteria can be identified by detecting the presence of ESBL encoding genes [26]. This research results showed that $b l a_{\text {TEM }}$ gene was found at $100 \%$ isolates and followed by $b l a_{\text {CTX-M }}(90.9 \%)$. The $b l a_{\text {SHV }}$ gene is only found in one isolate from $11 \mathrm{~K}$. pneumoniae isolates. Other studies of $K$. pneumoniae have been widely practiced. Some investigation showed that the dominant genotype found was the bla $a_{\text {СТХ-M }}$ gene [27,28]. The ESBL type was often seen as single or in combination. In this study, ESBL encoding genes were detected in all K. pneumoniae isolates from chicken.

Mobile genetic elements such as transposons, insertion sequences, and integrons in bacteria cause the ESBL gene to move quickly from animal to human or vice versa. The genetic factors could also spread the nature of resistance to other bacteria in the animal's gastrointestinal tract. The bacteria then spread from farm to surrounding environment through waste facilitated by bad hygiene and sanitation, which contaminate soil and water around farm. ESBL bacteria were also detected in vegetables, soil, and water around farm and market [28-30]. Contamination in chicken product and other foodstuff may happen if processing is not done with good hygiene $[4,6]$. This shows that ESBL bacteria not only cause nosocomial infection but also cause community infection and foodborne disease.

From the results of antimicrobial susceptibility test, it was known that all isolates of $K$. pneumoniae, also, having an ESBL gene were also an MDR bacteria.
The presence of MDR-ESBL bacteria is a threat to public health and livestock. These conditions could result in limited treatment options. Furthermore, MDRESBL bacteria triggered the use of antibiotic that has no longer been used for toxicity, such as colistin [31]. Measures that could be undertaken were building surveillance programs, conducting surveillance on feed and livestock. Breeders also need to improve biosecurity practice. Litter and manure waste must be properly managed in intensive production systems, to prevent the contamination of air, soil, and water, as well as negative consequences for human health [32].

\section{Conclusion}

Eleven K. pneumoniae isolates could be isolated from chicken cloacal swabs in the chicken farms in East Java. All K. pneumoniae were classified as MDR bacteria. Through PCR testing, ESBL encoding genes could be identified in all isolates. The presence of resistant encoding gene in bacteria has the potential to spread its resistance to the other bacteria in the gastrointestinal tract of chickens as well as in the livestock environment.

\section{Authors' Contributions}

MH designed the study and drafted the manuscript under the supervision of AI and NLPIM. NA and II collected samples and compiled the resource materials. $\mathrm{MH}$ and NA performed the test and data analysis under the supervision of II. MH conducted molecular detection of resistant gene by PCR under the supervision of AI and NLPIM. All authors have read and approved the final manuscript.

\section{Acknowledgments}

The authors would like to thank Mrs Sri Mukartini, Chief of National Veterinary Drug Assay Laboratory (NVDAL) for permission and support, staff of Bacteriology Division NVDAL, Bogor-Indonesia, for technical support, and also the staffs of Division of Medical Microbiology, Faculty of Veterinary Medicine, Bogor Agriculture Institute. This study was supported by funding from Agency of Agricultural Counseling and Human Resource Development, Ministry of Agriculture, Republic Indonesia.

\section{Competing Interests}

The authors declare that they have no competing interests.

\section{Publisher's Note}

Veterinary World remains neutral with regard to jurisdictional claims in published institutional affiliation

\section{References}

1. Fielding, B.C., Mnabisa, A., Gouws, P.A. and Morris, T. (2012) Antimicrobial-resistant Klebsiella species isolated from free-range chicken samples an informal settlement. Arch. Med. Sci., 8(1): 39-42. 
2. Shon, A.S., Bajwa, R.P.S. and Russo, T.A. (2013) Hypervirulent (Hypermucoviscous) Klebsiella pneumoniae: A new and dangerous breed. Virulence, 4(2): 107-118.

3. Gupta, A. (2002) Hospital-acquired infections in the neonatal intensive care unit--Klebsiella pneumoniae. Semin Perinatol., 26(5): 340-345.

4. Guo, Z.H., Qin, L., Pang, Z., Qin, T. and Ren, H. (2016) Frequency, antimicrobial resistance and genetic diversity of Klebsiella pneumoniae in food samples. PLoS One, 11(4): e0153561.

5. Mohammed-Aly, M., Khalil, S. and Metwaly, A. (2014) Isolation and molecular identification of Klebsiella spp. microbe isolated from chicks. Alex. J. Vet. Sci., 43(1): 97-103.

6. Wu, H., Wang, M., Liu, Y., Wang, X., Wang, Y., Lu, J. and $\mathrm{Xu}, \mathrm{H}$. (2016) Characterization of antimicrobial resistance in Klebsiella species isolated from chicken broilers. Int. J. Food Microbiol., 232: 95-102.

7. Kim, S.H, Wei, C.I, Tzou, Y.M. and An, H. (2005) Multidrug-resistant Klebsiella pneumoniae isolated from farm environments and retail products in Oklahoma. J. Food Prot., 68(10): 2022-2029.

8. Bidet, P., Burghoffer, B., Gautier, V., Brahimi, N. and Mariani-Kurkdjian, P. (2005) In vivo transfer of plasmid-encoded ACC-1 ampC from Klebsiella pneumoniae to Escherichia coli in an infant and selection of impermeability to imipenem in K. pneumoniae. Antimicrob. Agents Chemother., 49(8): 3562-3565.

9. Schjørring, S. and Krogfelt, K.A.S. (2008) Transfer of antimicrobial resistance plasmids from Klebsiella pneumoniae to Escherichia Coli in the mouse intestine. J. Antimicrob. Chemother., 62(5): 1086-1093.

10. Kaur, M. and Aggarwal, K. (2013) Occurrence of the CTX-M, SHV, and the TEM genes among the extended spectrum $\beta$-lactamase producing isolates of Enterobacteriaceae in a tertiary care hospital of North India. J. Clin. Diagn. Res., 7(4): 642-645.

11. Ashayeri-Panah, M., Feizabadi, M.M. and Eftekhar, F. (2014) Correlation of multi-drug resistance, integron and blaESBL gene carriage with genetic fingerprints of extended-spectrum $\beta$-lactamase producing Klebsiella pneumoniae. Jundishpur J. Microbiol., 7(2): 1-5.

12. Mobarak-Qamsari, M., Ashayeri-Panah, M., Eftekhar, F. and Feizabadi, M.M. (2013) Integron mediated multidrug resistance in extended-spectrum beta-lactamase producing clinical isolates of Klebsiella pneumoniae. Braz. J. Microbiol., 44(3): 849-854.

13. Arief, R.A., Darmawan, R.D., Sunandar, Widyastuti, M.D.W., Nugroho E, Jatikusumah A, Putra, A.A.G., Basuno, E., Karuniawati, A., Suwandono, A., Wiliyanto, I., Suandy, I. and Latif, H. (2016). The use of antibiotics in laying hens in Central Java, Indonesia. Konferensi Ilmiah Vet. Nasional, 14(1): 22-25.

14. Masruroh, C.A., Sudarwanto, M.B. and Latif, H. (2016) The occurrence of extended-spectrum $\beta$-lactamase-producing Escherichia coli from broiler feces in Bogor. J. Sound Vib., 34(3-4): 42-49.

15. Chander, Y., Jindal N.R., Hanson, K. and Goyal, S.M. (2011) Differentiation of Klebsiella pneumoniae and K. oxytoca by multiplex polymerase chain reaction. Int. J. Appl. Res. Vet. Med., 9(2): 138-142.

16. Clinical and Laboratory Standards Insitute. (2017) Performance Standards for Antimicrobial Susceptibility Testing. $27^{\text {th }}$ ed. CLSI Institute, Wayne (US).

17. European Committee on Antimicrobial Susceptibility Testing. (2018) Breakpoint Tables for Interpretation of MICs and Zone Diameters. Version 8.1. Available from: www.eucast.org. Last accessed on 07-08-2018.

18. Momtaz, H., Rahimi, E. and Moshkelani, S. (2012)
Molecular detection of antimicrobial resistance genes in $E$. coli isolated from slaughtered commercial chickens in Iran. Vet. Med., 57(4): 193-197.

19. Lymo, B., Buza, J., Subbiah, M., Smith, W. and Call, D.R. (2016) Comparison of antibiotic resistant Escherichia coli obtained from drinking water sources in Northern Tanzania: A cross-sectional study. BMC Microbiol., 16(1): 254.

20. Claeys, G., De Baere, T., Wauters, G., Vandecandelaere, P., Verscraegen, G. and Vaneechoutte, M.A. (2004) Extended-spectrum $\beta$-lactamase (ESBL) producing Enterobacter aerogenes phenotypically misidentified as Klebsiella pneumoniae or K. terrigena. BMC Microbiol., 49: 49.

21. Adekambi, T., Drancourt, M. and Raoult, D. (2008) The rроB gene as a tool for clinical microbiologists. Trends Microbiol., 17(1): 37-45.

22. Food and Agriculture Organization. (2008) Poultry Production and the Environment a Review. Animal Production and Health Division, Food and Agriculture Organization of the United Nations, Rome.

23. Michalova, E., Novotna, P. and Schelegelova J. (2004) Tetracyclines in veterinary medicine and bacterial resistance to them. Vet. Med. Czech, 49(3): 79-100.

24. World Health Organization. (2011) Tackling Antibiotic Resistance from a Food Safety Perspective in Europe. World Health Organization, Copenhagen (Denmark).

25. European Medicine Agency. (2016) Reflection Paper on Use of Aminoglycosides in Animals in the European Union: Development of Resistance and Impact on Human and Animal Health. European Medicine Agency, London (UK). Available from: http://www.ema.europa.eu/docs/ en_GB/document_library/Scientific_guideline/2017/07/ WC 500232227 .pdf. Last accessed on 07-08-2018.

26. Overdevest, I.T., Heck, M., Van der Zwaluw, K., Huijsdens, X., Van Santen, M., Rijnsburger, M., Eustace, A., $\mathrm{Xu}$, L., Hawkey, P., Savelkoul, P., VandenbrouckeGrauls, C., Willemsen, I., van der Ven, J., Verhulst, C. and Kluytmans, J.A. (2014). Extended-spectrum $\beta$-lactamase producing Klebsiella spp. In chicken meat and humans: A comparison of typing methods. Clin. Microbiol. Infect., 20(3): 251-255.

27. Zarfel, G., Galler, H., Luxner, J., Petternel, C., Reinthaler, F.F., Haas, D., Kittinger, C., Grisold, A.J., Pless, P. and Feierl, G. (2014) Multiresistant bacterial isolated from chicken meat in Austria. Int. J. Res. Public Health, 11(12): 12582-12593.

28. Ibrahim, I.A.J. and Hameed, T.A.K. (2015) Isolation, Characterization and antimicrobial resistance patterns of lactose-fermenter Enterobacteriaceae isolates from clinical and environmental samples. J. Med. Microbiol., 5: 169-176.

29. Puspanadan, S., Afsah-Hejri, L., Loo, Y.Y., Nillian, E., Kuan, C.H, Goh, S.G, Chang, W.S., Lye, Y.L., John, Y.H.T., Rukayadi, Y., Yoshitsugu, N., Nishibuchi, M. and Son, R. (2012) Detection of Klebsiella pneumoniae in raw vegetables using most probable number-polymerase chain reaction (MPN-PCR). Int. Food Res. J., 19(4): 1757-1762.

30. Wu, H., Wang, M., Liu, Y., Wang, X., Wang, Y., Lu, J. and $\mathrm{Xu}, \mathrm{H}$. (2016) Data on the phylogenetic typing, integrin gene cassette array analysis, multi-drug resistance analysis and correlation between antimicrobial resistance determinants in Klebsiella strains. Data Brief, 8: 1289-1294.

31. Fard, B. (2004) The effect of colistin sulfate in feed on the controlling of Salmonella enteritidis contamination in a broiler farm. Arch. Razi Inst., 58(1): 105-111.

32. Thyagarajan, D., Barathi, M. and Sakthivadivu, R. (2014) Risk mitigation of poultry industry pollutants and waste for environmental safety. Glob. J. Sci. Front. Res. Agric. Vet., 14(1): 1-10. 